\title{
Movement patterns of stream-dwelling fishes from Mata Atlântica, Southeast Brazil
}

\section{Rosana Mazzoni ${ }^{1}$ \& Ricardo Iglesias-Rios ${ }^{2}$}

1. Laboratório de Ecologia de Peixes, Departamento de Ecologia, Instituto de Biologia Roberto Alcantara Gomes, Universidade do Estado do Rio de Janeiro. Av. São Francisco Xavier 524, CEP 20550-013, Rio de Janeiro, RJ, Brasil; mazzoni@uerj.br

2. Universidade Federal do Rio de Janeiro / Instituto de Biologia / Departamento de Ecologia. C.P. 68020, Rio de Janeiro, RJ. Brasil; rir@biologia.ufrj.br

Received 26-X-2011. Corrected 09-V-2012. Accepted 11-VI-2012.

\begin{abstract}
The identification of mechanisms of spatial-temporal variation, obtained from the quantification of natural populations, is a central topic of ecological research. Despite its importance to life-history theory, as well as to conservation and management of natural populations, no studies concerning movement patterns and home range of small stream-dwelling fishes from Brazilian rain forests are known. In the present study we aimed to describe the longitudinal pattern of long distance movement as well as local patterns of short movement (daily home-range) of fishes from a Mata Atlântica stream from Southeast Brazil. We gathered information about movement dynamic in order to discuss the relationship between swimming ability, fish morphology and home range. Long distance movement data were obtained in a mark-recapture experiment held in the field between June and September - 2008, on five sites along the Ubatiba stream. For this study, we had one day to mark fishes, on June-19, and 14 events for recapture. Considering the ten species that inhabit the study area, our study showed that four species: Astyanax janeiroensis, Astyanax hastatus, Parotocinclus maculicauda and Pimelodella lateristriga, moved at least $6000 \mathrm{~m}$ in 60 days. The other six species did not present long distance movements, as they were recaptured in the same site 90 days after being marked. For short distance study, movement data were obtained in one mark-recapture experiment held in a $100 \mathrm{~m}$ long site subdivided into five $20 \mathrm{~m}$ stretches where fishes were marked with different elastomer colours. We marked 583 specimens that after recapture showed two groups of different movement patterns. The first group was called "Long Movement Group" and the second one was called "Short Movement Group". The Long Movement Group showed, on average, 89.8\% of moving fishes and $10.2 \%$ of non moving fishes, against $21.3 \%$ and $78.7 \%$, respectively, for the Short Movement Group. It was concluded that fish movement could explain the previously mentioned community stability, and that it is correlated to specific morphological attributes. Rev. Biol. Trop. 60 (4): 1837-1846. Epub 2012 December 01.
\end{abstract}

Key words: migration, home-range, life history, Characins, Siluroidei, Brazil.

The identification of mechanisms of spatial-temporal variation, obtained from the quantification of natural populations, is a central topic of ecological research (Copp \& Jurajda 1993, Lobón-Cerviá \& Rincón 2004, Okun \& Mehner 2005). Most of the present studies, focusing on fish population dynamics, are predominantly based on the negative feedbacks between density and demographic factors for the populations, such as, mortality or fecundity (Wootton 1998). This may explain the continuous increase of interest in the role of fish movement and home range as a key factor for the dynamic patterns and size of fish populations (Schuck 1945, Saunders \& Gee 1964, Lucas \& Baras 2001, Polis et al. 2004).

Given the importance of such studies in the context of ecological theory, the high number of models developed to assess the movement of fish in temperate regions is well known, mainly for the breeding migrations of salmon from North America and European rivers. These 
environments can be considered as quite stable, with comparatively reduced habitat heterogeneity from climatic impacts (Winemiller 1991, Gowan et al. 1994, Wootton \& Oemke 1992, Mazzoni \& Lobón-Cerviá 2000).

In the tropics, however, seasonal climatic variations are less marked, with consequent reduced change in the resource availability. This complicates the predictability of the movement pattern of fish and, therefore, it is expected that both the short, daily migrations for feeding and refuge, as well as long-distance seasonal migrations for reproduction are much less regular among these tropical fish than among fish populations from temperate areas (Winemiller \& Jepsen 1998, Ostrand \& Wilde 2002, Granado-Lorencio 2005, McMahon \& Matter 2006). Nonetheless, it is expected that in the tropics the movement pattern of fish, similar to what occurs in temperate communities, is a key factor for size, as well as for dynamic patterns of fish populations and communities (Winemiller \& Jepsen 1998, Arrington \& Winemiller 2003, Mazzoni et al. 2004).

No studies concerning movement patterns and home range of small stream-dwelling fishes from Brazilian rain forests are known, however, previous studies were mainly based on patterns of diversity and population/community structure obtained in studies about longitudinal and lateral distribution (Menezes \& Caramaschi 1994, Mazzoni \& Lobón-Cerviá 2000, Mazzoni et al. 2004, Mazzoni et al. 2005, Rezende et al. 2010). In the present study we aimed to describe, based on markrecapture experiments, the longitudinal pattern of long and short distance movement of fishes from Ubatiba stream. We gathered information about movement dynamic in order to discuss the relationship between this swimming ability, fish morphology and home range.

\section{MATERIALS AND METHODS}

Study area: The Ubatiba stream $\left(22^{\circ} 60^{\prime}\right.$ S - 42 $48 "$ W) composes a typical small Serra do Mar fluvial system $(\approx 16 \mathrm{~km}$ long, $42 \mathrm{~km}^{2}$ ) located $70 \mathrm{~km}$ North from Rio de
Janeiro city (Brazil). It is a low altitude stream $(<30$ m.a.s.1.), which waters flow through meadows deforested for agricultural practices and cattle ranching. However, some patches of pristine Mata Atlântica forest are still left on some slopes and tops of the surrounding rocky hills. The Ubatiba stream discharges in Maricá Lagoon, a large brackish water lagoon formed by the accumulation of offshore sand dunes. The water flow is solely regulated by, and fluctuates according to, rainfall $(\approx 1500 \mathrm{~mm} / \mathrm{y})$ with a run-off and increased fluctuations in summer (October-January, $1300 \mathrm{~mm}$ ) as compared to winter (May/July, 150mm). Severe tropical storms $(>120 \mathrm{~mm}$ a day) may increase water discharge by three-fold within a few hours, but a return to the original discharge can occur within the same day. Twenty-two species compose the Ubatiba ichthyofauna (Costa 1984, Mazzoni \& Lobón-Cerviá 2000).

Sampling and data analysis: The patterns of both short and long-distance movement of the fish species from Ubatiba stream were analysed. Long-distance movement was determined by a mark-recapture method, between June and September-2008, considering fish movement between five sites along the $10 \mathrm{~km}$ of the Ubatiba stream. Each site was positioned $2 \mathrm{~km}$ apart from each other and was $150 \mathrm{~m}$ long, encompassing all meso-habitats present along the stream. At each site, marking event occurred on June-19 $9^{\text {th }} 2008$, and recapture events occurred on June-26, July-02, 10, 17, 24 and 31, August-07, 17, 21 and 28 and September-04, 11, 18 and 25. Samples were done by electrofishing $(1000 \mathrm{~W}, 220 \mathrm{~V}, 2-4 \mathrm{~A}$ - Mazzoni et al. 2000) through the successive removal method (Zippin 1958) until no fishes were found in the study site. During sampling the two extreme points of sampling site were closed with nets (mesh size $0.5 \mathrm{~cm}$ ) to avoid any fish escape. During subsequent removals, sampled fishes were placed in floating cages and kept alive outside of the effect of electricity. At the first sampling occasion (marking event) all sampled individuals were measured and marked, at the base of the dorsal fin, 
with colored elastomer (Visible Implant Elastomers-Northwest Marine Technology, Inc.) with a specific colour for each site. Marked fish were returned to the river at the midpoint of the sampling site. Long-distance movement was assessed by quantification of individuals recaptured inside and outside of their marking site. We considered as resident individuals those fishes recaptured inside their marking site, and moving individuals those recaptured outside their marking sites. The distance covered by moving individuals was determined as the distance in meters between the marking subsection and the subsection where the individual was recaptured. The distance covered by each species was considered as the maximum distance covered by individuals of the same species.

One experiment aiming to describe short distance movement (daily home-range) was held in the field on July-2009 and followed Skyfield \& Grossman (2008). One site, 100m long, was divided in five subsections of $20 \mathrm{~m}$ isolated from each other with closing nets ( $5 \mathrm{~mm}$ mesh size). At each subsection all fishes were collected by electrofishing $(1000 \mathrm{~W}$, $220 \mathrm{~V}, 2-4 \mathrm{~A}$ ), applying the successive removal method (Zippin 1958) until no fishes were found. All sampled individuals were marked with colored elastomer at the base of the dorsal fin with a specific colour for each subsection according to the criteria presented in figure 1 . Once we had finished the marking phase, fishes were returned to the river in the same subsection where they had been captured. We waited $30 \mathrm{~min}$ and after that, we carefully removed the closing nets, allowing fish to move freely outside and between all subsections. Six hours after the last net removal we reintroduced the closing nets exactly in the same positions where they were during the marking phase; fishes were again electrofished at each sub section separately (recapture phase). The indicatives of absence or presence of fish movement were classified according to the following criteria: (i) non recaptured fish=fishes moving out of the study site-indicative of fishes that moved out of the study site; (ii) non moving recaptured fish-indicative of non moving fish that were recaptured in the same subsection where they had been marked; (iii) moving fishindicative of fish moving in or out of the study site, this was considered as the sum of all individuals recaptured below, recaptured above and non recaptured; (iv) individuals without marks captured during the recapture phase-indicative of fishes moving to the study site. The patterns of short-distance movement were examined by counting the individuals obtained during the recapture phase, considering the presented criteria (i.e. if fishes were in their original sub section or if they moved out of it).

\section{RESULTS}

Ten species were registered in the study area: Astyanax janeiroensis Eigenmann, 1908, Astyanax hastatus Myers, 1928, Pimelodella lateristriga (Lichtenstein 1823), Parotocinclus maculicauda (Steindachner 1877), Hoplias malabaricus (Bloch 1794), Characidium interruptum Pellegrin 1909, Mimagoniates microlepis (Steindachner 1877), Phalloceros harpagos

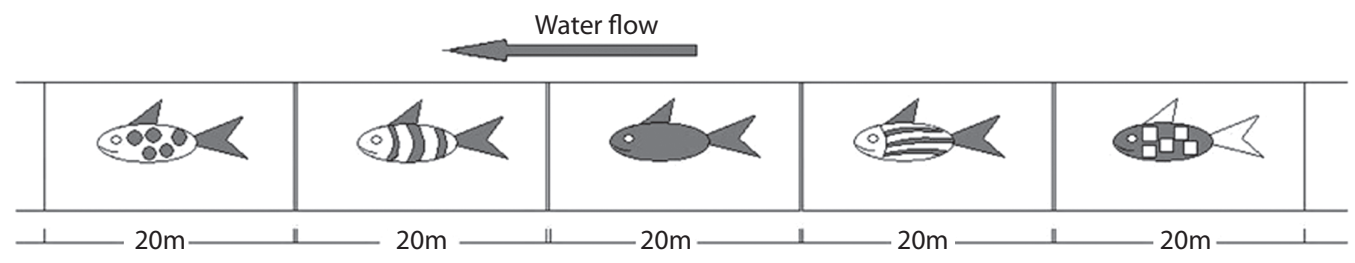

Fig. 1. Marking system used to analyse short distance movement of fish from the Ubatiba stream, Maricá - RJ. Sub section 1 - circles=Orange elastomer; Sub section 2 - vertical lines=blue elastomer; Sub section 3 - full grey=yellow elastomer; Sub section 4 - horizontal lines=red elastomer; Sub section 5 - squares=green elastomers. 
Lucinda 2008, Geophagus brasiliensis (Quoy \& Gaimard 1824) and Rhamdia sp. Bleeker 1858. The analyses of long distance movement showed that $A$. janeiroensis and A. hastatus moved at least $6000 \mathrm{~m}$ in 56 days after being marked. P. maculicauda moved at least $6000 \mathrm{~m}$ in 63 days. Recaptures of Astyanax species occurred on August 17 and of P. maculicauda occurred on August 21. P. lateristriga moved $4000 \mathrm{~m}$ in 84 days and were recaptured on September 11. The other species did not present long distance movements; they were recaptured in the same site 90 days after being marked (Table 1).

For the short distance movement study we marked 583 individuals of the ten species registered in the study site. Three-hundred and twenty-three marked individuals (57.1\%) were recaptured, $250(42.8 \%)$ were not and 233 fishes without marking elastomers were sampled during the recapture phase. Based on the number of recaptures of marked and/or non marked fishes we observed that movement patterns varied among the species and distinguished two moving groups.

The first group, called "Long Movement Group" (Table 2), was formed by $A$. janeiroensis, A. hastatus, P. lateristriga and $P$. maculicauda. This group presented high values of non-recaptured fishes (MovO), small values of fishes that were recaptured in the same subsection where they had been marked (nMov), high values of non marked individuals that were captured during the recapture event (nMrk) and high values of moving individuals (MovB and MovA) that were recaptured outside their marking sub section (Table 2).

Astyanax janeiroensis showed $94.6 \%$ of moving individuals, with $32.1 \%$ being recaptured outside their marking subsection; $67.9 \%$ were not recaptured. Maximum displacement was $20.0 \mathrm{~m} / 6 \mathrm{~h}$ and $80.0 \mathrm{~m} / 6 \mathrm{~h}$ for sub sections below and above from their marking sub section, respectively (Table 2, Fig. 2). Astyanax hastatus showed $80.4 \%$ of moving individuals, with $14.4 \%$ being recaptured outside their marking subsection; $85.6 \%$ were not recaptured. Maximum displacement was $40.0 \mathrm{~m} / 6 \mathrm{~h}$ and $80.0 \mathrm{~m} / 6 \mathrm{~h}$ for subsections below and above from their marking subsection, respectively (Table 2, Fig. 2). Pimelodella lateristriga showed $89.7 \%$ of moving individuals, with $48.6 \%$ being recaptured outside their marking subsection; $51.4 \%$ were not recaptured.

TABLE 1

Long distance study results for the fish species inhabiting the middle stretch of Ubatiba stream, Maricá Rio de Janeiro, Brazil

\begin{tabular}{|c|c|c|c|c|c|c|c|c|c|c|}
\hline \multirow{2}{*}{ Species } & \multirow{2}{*}{$\begin{array}{l}\text { MF } \\
\text { (n) }\end{array}$} & \multirow{2}{*}{$\begin{array}{l}\text { RF } \\
\text { (n) }\end{array}$} & \multirow{2}{*}{$\begin{array}{l}\text { RF } \\
(\%)\end{array}$} & \multirow{2}{*}{ Direction } & \multicolumn{6}{|c|}{ Distances (m) } \\
\hline & & & & & 0 & 2000 & 4000 & 6000 & 8000 & 10000 \\
\hline Astyanax janeiroensis & 49 & 6 & 12.2 & upstream & 5 & & & $1(8)$ & & \\
\hline Astyanax hastatus & 57 & 9 & 15.8 & upstream & 7 & & & $2(8)$ & & \\
\hline Hoplias malabaricus & 13 & 13 & 100.0 & & 13 & & & & & \\
\hline Pimelodella lateristriga & 38 & 7 & 18.4 & upstream & 5 & & $2(12)$ & & & \\
\hline Rhandia quelen & 4 & 3 & 75.0 & & 3 & & & & & \\
\hline Parotocinclus maculicauda & 39 & 5 & 12.8 & upstream & 3 & & & 2(9) & & \\
\hline Characidium interruptum & 23 & 5 & 21.7 & & 5 & & & & & \\
\hline Mimagoniates microlepis & 17 & 4 & 23.5 & & 4 & & & & & \\
\hline Phallocerus harpagos & 61 & 56 & 91.8 & & 56 & & & & & \\
\hline Geophagus brasiliensis & 35 & 6 & 17.1 & & 6 & & & & & \\
\hline Total & 403 & 175 & 43.4 & & & & & & & \\
\hline
\end{tabular}

Number of marked fish $(\mathrm{MF}(\mathrm{n}))$, recaptured fish $(\mathrm{RF}(\mathrm{n}))$, percentage of recaptured fish (RF (\%)), movement direction (Direction) and number of recaptured fishes according to the covered distance (Distance $-\mathrm{m}$ ). Numbers in parenthesis refer to sampling date. 


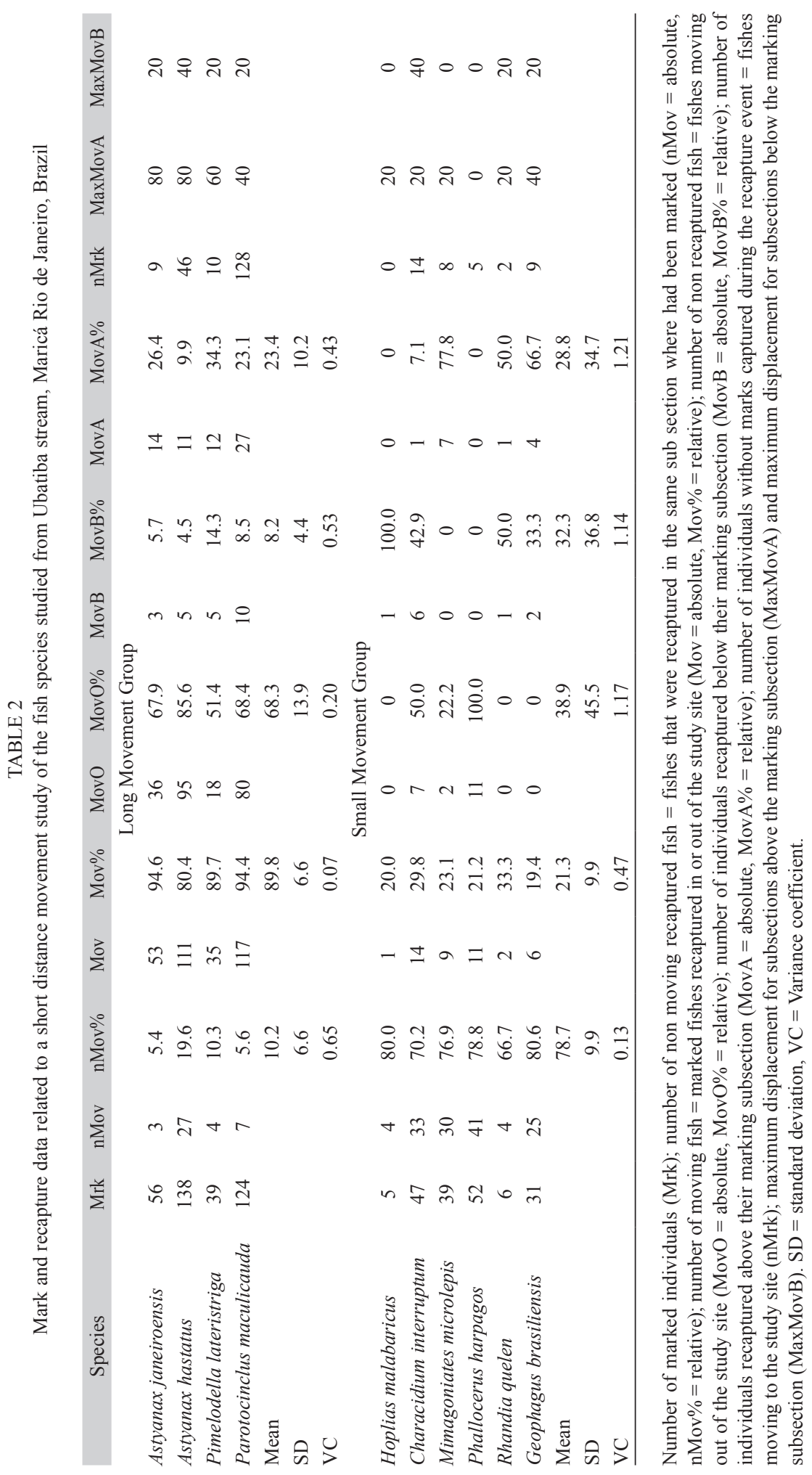




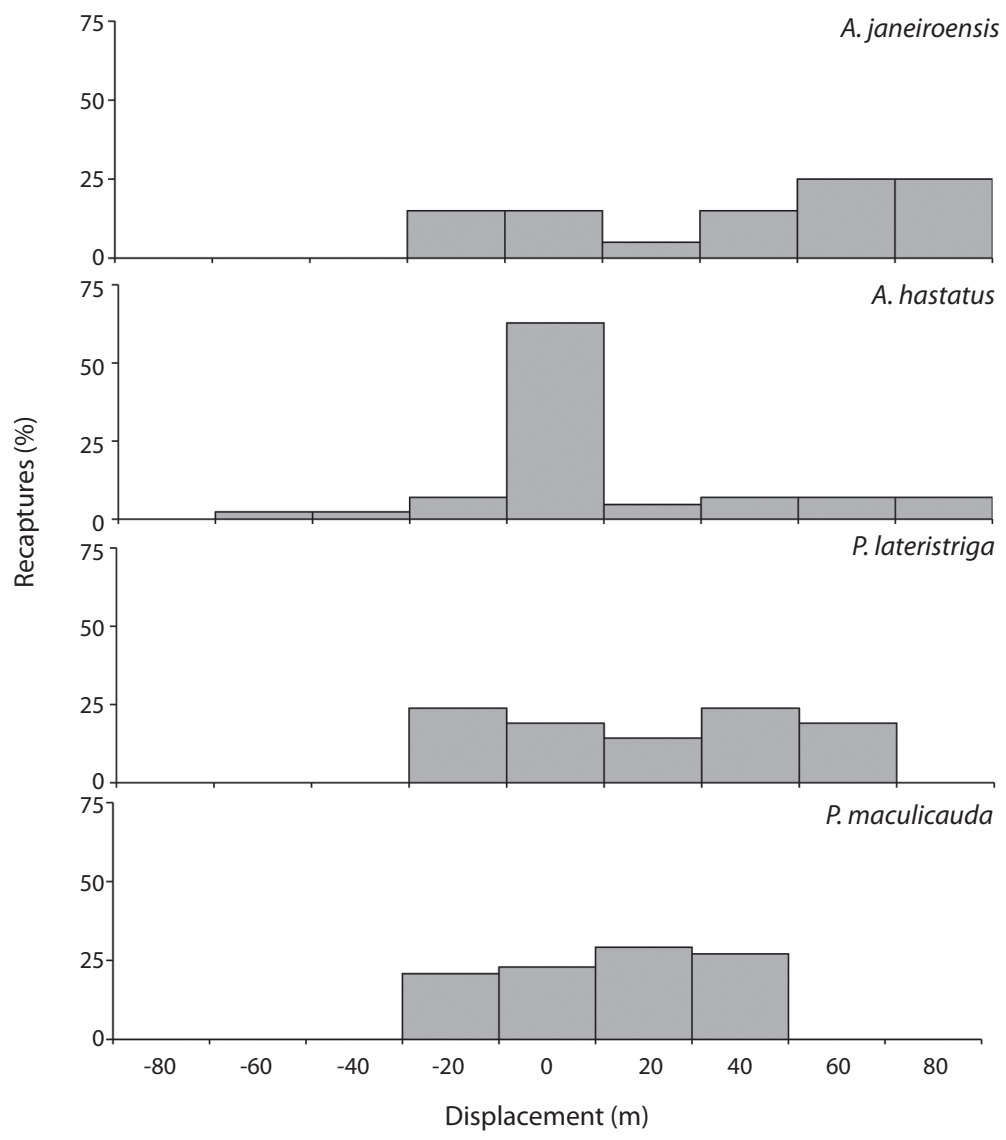

Fig. 2. Displacement of the "Long Movement Group" fishes from Ubatiba stream. Site 0 (zero) corresponds to the marking subsection, positive and negative numbers correspond to above and below displacement, respectively.

Maximum displacement was $20.0 \mathrm{~m} / 6 \mathrm{~h}$ and $60.0 \mathrm{~m} / 6 \mathrm{~h}$ for subsections below and above from their marking subsection, respectively (Table 2, Fig. 2). Parotocinclus maculicauda showed $94.4 \%$ of moving individuals, with $31.3 \%$ being recaptured outside their marking sub section; $68.4 \%$ were not recaptured. Maximum displacement was $20.0 \mathrm{~m} / 6 \mathrm{~h}$ and $40.0 \mathrm{~m} / 6 \mathrm{~h}$ for subsections below and above from their marking sub section, respectively (Table 2, Fig. 2).

The second group, called "Short Movement Group" (Table 2) presented high values of recaptured fish (Rc) and low values of fishes moving inside and outside the study area. Only $19 \%$ of the marked individuals showed some evidence of movement (e.g. recapture outside their marking subsection and non-recaptured fish). Among the six species comprising this group, five (H. malabaricus, C. interruptum, M. microlepis, G. brasiliensis and R. quelen) showed short movement between the subsections, whereas one, P. harpagos, did not move during the study time (Table 2, Fig. 3).

\section{DISCUSSION}

Movement of an organism, defined as a change in the spatial location of the whole individual in time, is a fundamental characteristic of life, driven by process that can act across multiple temporal and spatial scales (Nathan et 

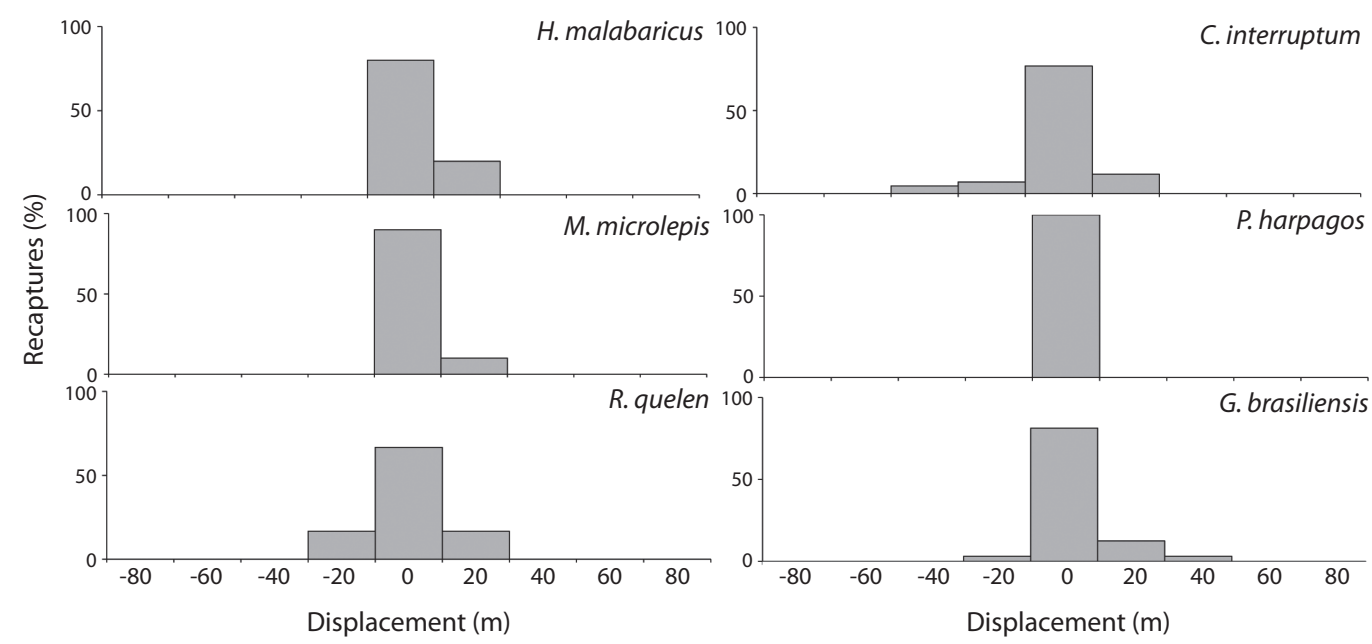

Fig. 3. Displacement of the "Small Movement Group" fishes from Ubatiba stream. Site 0 (zero) corresponds to the marking sub section, positive and negative numbers correspond to above and below displacement, respectively.

al. 2008). Animal movement has a basic role in the organization of populations and communities, and has been considered as one of the main determinants of the stability of fish communities. The rates of fish movement are highly correlated to fish densities, thus, responding to community persistence (Martin-Smith et al. 1999). Among the ten species recorded in the study area only four showed evidence of movement equal or longer than $20 \mathrm{~m}$. These four species are the ones presenting higher densities in all sites along the stream (Mazzoni et al. 2006), thus they are the species effectively responsible for the community structure of Ubatiba stream (sensu Grossman, 1982). Following this, the movement pattern showed by these four species could explain the highly temporal stability previously mentioned by Mazzoni \& LobónCerviá (2000) to the Ubatiba fish community.

Fish with restricted home ranges face different challenges than the ones that travel over large areas. Our results have shown clear differences in the movement pattern of the studied species. Mean values of recaptured individuals of each species showed that the first group belonging to the "Long Movement Group" was more homogeneous than the one belonging to the "Short Movement Group". The distance and habitat over which animals move have an important bearing on the fitness and ultimately, on the structure of populations. The spatial and temporal scales across which animals use habitats is of particular importance for meeting individual requirements and hence the survival of a species (Woolnough et al. 2009). In general, the spatial and temporal scale at which an individual utilizes various resources should match the relative importance of each limited resource. Thus, many studies have shown that for mobile species movement and home range are positively related with resource availability (Schlosser 1991, Schrank \& Rahel 2004).

According to Nathan (2008), the home range of a species normally reflects the distances travelled by individuals of a population and is defined as a measure of total effort spent for the development of the whole vital activities (e.g. feeding, reproduction and shelter). However, many studies have shown that movement patterns in a given area are positively related to feeding requirements and food availability (Huey \& Pianka 1981), territoriality (Hansen \& Closs 2005), stream/river size (Woolnough et al. 2009) and fish body size (Haskell et al. 2002) among others. In the present study we did not find correlation between fish size 
(expressed as fish standard length) and home range, but the other characters previously mentioned were not tested due to the absence of data concerning those life history attributes for Mata Atlântica streams.

With increasing fragmentation of water bodies worldwide, knowledge about the extension of the habitat used by fish species is imperative (Downing et al. 2006). It has been observed that in temperate regions, factors such as time of the year, reproductive season and environmental characters are important in defining movement patterns of stream-dwelling fishes and could be responsible for temporal patterns of community structure as well (Hansen \& Closs 2005). Few studies concerning movement patterns and home range of tropical fishes are known. Among all known records we highlight those related to large rivers from Amazonian, Paraná, Uruguay and other large basins (Goulding 1980, Agostinho et al. 2003, Alves 2007, Alves et al. 2007, Antonio et al. 2007, Fernadez et al. 2007, Tejerina-Garro \& Merona 2010). Although there are no movement studies for stream-dwelling fish communities from Mata Atlântica, Mazzoni et al. (2004) registered some evidences of upstream migration related to reproduction among a Characiform species from a coastal stream in Southeast Brazil. Our results confirm the findings of Mazzoni et al. (2004) about the movement ability of some Characiforms and are strong indicators that other species in the group "Long Movement Group" have broader home range as a consequence of migration.

We noticed that the various species that composed the community of the study area differed as to the temporal patterns of movement. Although our experiments have covered only a small period of field study, we observed that fish species gathered in two large groups characterized by distinct patterns of movement. The first group, so called "Long Movement Group", was formed by A. janeiroensis and A. hastatus, "tetras" species of Characidae included in the incertae sedis group (sensu Reis et al. 2003) and by the Siluroidei $P$. lateristriga and $P$. maculicauda. In fact, the ability to swim and displace have been recurrently observed for these characids and catfish species (Casatti \& Castro 2006). The morphological design of some catfishes has been also associated to the swimming behaviour and could explain the high values of movement registered to $P$. lateristriga and P. maculicauda. Our results support these observations, since the four mentioned species showed shifts at distances up to $4000 \mathrm{~m}$ over a period of 60 or 90 days. The other species mentioned in the present study have been poorly explored, with no or incomplete knowledge about their life history. Nonetheless, they are known by their benthonic behaviour and the association to marginal or sheltered areas in the streams where they occur (Mazzoni \& IglesiasRios 2002a, Mazzoni \& Iglesias-Rios 2002b, Casatti \& Castro 2006).

We conclude that stream-dwelling fishes from Ubatiba showed different patterns of movement and home range. There is one group of long movement with maximum displacement of $80.0 \mathrm{~m} / 6 \mathrm{~h}$ and $60.0 \mathrm{~m} / 6 \mathrm{~h}$ to, respectively, above and below of the marking site and one group of short movement with maximum displacement of $20.0 \mathrm{~m} / 6 \mathrm{~h}$, to both above and below of the marking site. Among the long movement group we noticed a homogeneous group being recognized because of the low coefficient of variation of mean values of displacement. Nonetheless, the group concerning the low movement species was largely heterogeneous, composed by resident species without movement and resident species, with low mobility. In addition, these patterns of fish movement should reflect some morphological patterns.

Data on movement patterns of the studied species were obtained from an experiment conducted in a single season so that these results should be treated with caution. Nonetheless, considering that there are no data about the movement patterns of stream-dwelling fish from Mata Atlântica these are valuable results as the first report about the subject in streams and can serve as a basis for more refined analysis involving the movement patterns and their 
relationships with other aspects of the life history of Neotropical stream-dwelling fish.

\section{ACKNOWLEDGMENT}

We acknowledge to the staff of Laboratório de Ecologia de Peixes/Universidade do Estado do Rio de Janeiro for helping in the field work. To Javier Lobón-Cerviá (MNHN/ CSIC - Madrid) for the comments in the early draft of the manuscript. This research was supported by Conselho Nacional de Desenvolvimento Científico e Tecnológico - CNPq, Brazil (47086/2008-3 and 301433/2007-0).

\section{RESUMEN}

A pesar de su importancia en la investigación ecológica, no se conocen estudios sobre patrones de movimiento y del ámbito de hogar de peces que habitan pequeños ríos de los bosques tropicales brasileños. El objetivo del presente estudio fue describir los patrones de movimiento de larga y corta distancia de peces de un arroyo de la Mata Atlântica (2260" S - 42॰48” W). Los datos de los movimientos de larga distancia se obtuvieron mediante un experimento de marcación-recaptura realizado en cinco sitios distribuidos a lo largo de $10 \mathrm{~km}$ del río Ubatiba. Considerando las diez especies que habitan el área de estudio, observamos que cuatro se movieron por lo menos $6000 \mathrm{~m}$ en 60 días. Las otras seis especies no presentaron movimientos de larga distancia. Para los estudios de corta distancia se obtuvieron datos de marcación-recaptura en un sitio de muestreo con $100 \mathrm{~m}$ de longitud subdividido en cinco tramos de río con $20 \mathrm{~m}$. Los especímenes recapturados presentaron dos grupos con patrones distintos de movimiento; un grupo con mayor movimiento y otro grupo de poco movimiento. Concluímos que el movimiento de los peces podría explicar la estabilidad de la comunidad previamente mencionada, y que está correlacionado a los atributos morfológicos específicos.

Palabras clave: migración, ámbito de hogar, historia de vida, Characinos, Siluroidei, Brasil.

\section{REFERENCES}

Agostinho, A.A., L.C. Gomes, H.I. Suzuki \& H.F. Julio-Jr. 2003. Migratory fish of the upper Paraná River basin, Brazil, p. 19-98. In J. Carolsfeld, B. Harvey, C. Ross \& A. Baer (eds.). Migratory Fishes of South America: Biology, Fisheries and Conservation Status. IDRC and World Bank, Britsh Columbia, Canada.
Alves, C.B.M. 2007. Evaluation of fish passage through the Igarapé Dam fish ladder (rio Paraopeba, Brazil), using marking and recapture. Neotrop. Ichthyol. 5: 233-236.

Alves, C.B.M., L.G.M. Silva \& A.L. Godinho. 2007. Radiotelemetry of a female jaú, Zungaro jahu (Ihering, 1898) (Siluriformes: Pimelodidae), passed upstream of Funil Dam, rio Grande, Brazil. Neotrop. Ichthyol. 5: 229-232.

Antonio, R.R., A.A. Agostinho, F.M. Pelicice, D. Bai1ly, E.K. Okada \& J.H.P. Dias. 2007. Blockage of migration routes by dam construction: can migratory fish find alternative routes? Neotrop. Ichthyol. 5: 177-184.

Arrington, D.A. \& K.O. Winemiller. 2003. Diel changeover in sandbank fish assemblages in a Neotropical floodplain river. J. Fish Biol. 63: 442-459.

Casatti, L. \& R.M.C. Castro. 2006. Testing the ecomorphological hypothesis in a headwater riffles fish assemblage of the rio São Francisco, southeastern Brazil. Neotrop. Ichthyol. 4: 203-214.

Copp, G.H. \& P. Jurajda. 1993. Do small fish move inshore at night? J. Fish Biol. 43: 229-241.

Costa, W.J.E.M. 1984. Peixes fluviais do sistema lagunar de Maricá, Rio de Janeiro, Brasil. Atlântica 7: 65-72.

Downing, J.A., Y.T. Prairie, J.J. Cole, C.M. Duarte, L.J. Tranvik, R.G. Striegl, W.H. McDowell, P. Kortelainen, N.F. Caraco, J.M. Melack \& J. Middleburg. 2006. The global abundance and size distribution of lakes, ponds, and impound- ments. Limnol. Oceanogr. 51: 2388-2397.

Fernandez, D.R., A.A. Agostinho, L.M. Bini \& F.M. Pelicice. 2007. Diel variation in the ascent of fishes up an experimental fish ladder at Itaipu Reservoir: fish size, reproductive stage and taxonomic group influences. Neotrop. Ichthyol. 5: 215-222.

Goulding, M. 1980. The fishes and the forest: Explorations in Amazonian Natural History. University of California, Berkeley, California, USA.

Gowan, C., M.K. Young, K.D. Fausch \& S.C. Riley. 1994. Restricted movement in resident stream salmonids: a paradigm lost? Can. J. Fish. Aquat. Sci. 51: 2626-2637.

Granado-Lorencio, C., R.M.A. Lima \& J. Lobón-Cerviá. 2005. Abundance-distribution relationships in fish assembly of the Amazonas floodplain lakes. Ecography 28: 515-520.

Grossman, G.D. 1982. Dynamics and organization of a rocky intertidal fish assemblage: the persistence and resilience of taxocenose structure. Am. Nat. 119: 611-637.

Hansen, A. \& G.P. Closs. 2005. Diel activity and home range size in relation to food supply in a drift-feeding stream fish. Behav. Ecol. 16: 240-248. 
Haskell, J.P., M.E. Ritchie \& H. Olff. 2002. Fractal geometry predicts varying body size scaling relationships for mammal and bird home ranges. Nature 418: 527-529.

Huey, R.B. \& E.R. Pianka. 1981. Ecological consequences of foraging mode. Ecology 62: 991-999.

Lobón-Cerviá, J. \& P.A. Rincón. 2004. Environmental determinants of recruitment and their influence on the population dynamics of stream-living brown trout Salmo trutta. Oikos 105: 641-646.

Lucas, M. \& E. Baras. 2001. Migration of freshwater fishes. Blackwell Science, Oxford, England.

Martin-Smith, K.M., L.M. Laird, L. Bullough \& M.G. Lewis. 1999. Mechanisms of maintenance of tropical freshwater fish communities in the face of disturbance. Philos. Trans. R. Soc. Lond. B. Biol. Sci. 354: 1803-1810.

Mazzoni, R. \& J. Lobón-Cerviá. 2000. Longitudinal structure, density and production rates of a Neotropical stream fish assemblage: the river Ubatiba in the Serra do Mar (South-East Brazil). Ecography 23: 588-602.

Mazzoni, R., N. Fenerich-Verani \& E.P. Caramaschi. 2000. Electrofishing as a sampling technique for coastal stream fish populations and communities in the southeast of Brazil. Rev. Bras. Biol. 60: 205-216.

Mazzoni, R. \& R. Iglesias-Rios. 2002a. Distribution pattern of two fish species in a coastal stream in Southeast Brazil. Brazil. J. Biol. 62: 171-178.

Mazzoni, R. \& R. Iglesias-Rios. 2002b. Environmentally related life history variations in Geophagus brasiliensis. J. Fish. Biol. 61: 1606-1618.

Mazzoni, R., S.A. Schubart \& R. Iglesias-Rios. 2004. Longitudinal segregation of Astyanax janeiroensis in Rio Ubatiba: a Neotropical stream of south-east Brazil. Ecol. Fresh. Fish 13: 231-234.

Mazzoni, R., R.S. Mendonça \& E.P. Caramaschi. 2005 Reproductive biology Astyanax janeiroensis (Osteichthyes, Characiidae) from the Ubatiba River, Maricá - RJ. Brazil. J. Biol. 65: 643-649.

Mazzoni, R., N. Fenerich-Verani, E.P. Caramaschi \& R. Iglesias-Rios. 2006. Stream-dwelling fish communities from an Atlantic rain forest drainage. Braz. Arch. Biol. Technol. 49: 249-256.

McMahon, T. \& W.J. Matter. 2006. Linking habitat selection, emigration, and population dynamics of freshwater fishes: a synthesis of ideas and approaches. Ecol. Fresh. Fish 15: 200-210.

Menezes, M.S. \& E.P. Caramaschi. 1994. Características reprodutivas de Hypostomus gr. punctatus do rio Ubatiba, Maricá - RJ (Osteichthyes, Siluriformes). Rev. Bras. Biol. 54: 503-513.

Nathan, R. 2008. An emerging movement ecology paradigm. Proc. Natl. Acad. Sci. 105: 19050-19051.

Nathan, R., W.M. Getz, E. Revilla, M. Holyoak, R. Kadmon, D. Saltz \& P.E. Smouse. 2008. A movement ecology paradigm for unifying organismal movement research. Proc. Natl. Acad. Sci. 105: 19052-19059.

Okun, N. \& T. Mehner. 2005. Distribution and feeding of juvenile fish on invertebrates in littoral reed (Phragmites) stands. Ecol. Fresh. Fish 14: 139-149.

Ostrand, K.G. \& G.R. Wilde. 2002. Seasonal and spatial variation in a prairie stream-fish assemblage. Ecol. Fresh. Fish 11:137-149.

Polis, G.A., M.E. Power \& G.R. Huxel. 2004. Food webs at the landscape level. The University of Chicago, Chicago, Illinois, USA.

Reis, R.E., S.O. Kullander \& C.J. Ferraris Jr. 2003. Check list of the freshwater fishes of South and Central America. Edipucrs, Porto Alegre, Rio Grande do Sul, Brasil.

Rezende, C.F., M. Moraes, L.R. Manna, R.P. Leitão, E.P. Caramaschi \& R. Mazzoni. 2010. Mesohabitat indicator species in a coastal stream of the Atlantic rainforest, Rio de Janeiro-Brazil. Rev. Biol. Trop. 58: 1479-1487.

Saunders, R.L. \& J.H. Gee. 1964. Movements of young Atlantic salmon in a small stream. J. Fish. Res. B. Can. 21: 27-36.

Schlosser, I.J. 1991. Stream fish ecology: a landscape perspective. BioScience 41: 704-712.

Schrank, A.J. \& F.J. Rahel. 2004. Movement patterns in inland cutthroat trout: management and conservation implications. Can. J. Fish. Aquat. Sci. 61: 1528-1537.

Schuck, H.A. 1945. Survival, population density, growth and movement of the wild brown trout in Crystal Creek. Trans. Am. Fish. Soc. 73: 209-230.

Skyfield, J.P. \& G.D. Grossman. 2008. Microhabitat use, movements and abundance of gilt darters (Percina evides) in southern Appalachian (USA) streams. Ecol. Fresh. Fish 17: 219-230.

Tejerina-Garro, F.L. \& B. Mérona. 2010. Flow seasonality and fish assemblage in a tropical river, French Guiana, South America. Neotrop. Ichthyol. 8: 145-154.

Winemiller, K.O. 1991. Ecomorphological diversification of freshwater fish assemblages from five biotic regions. Ecol. Monog. 61: 343-365.

Winemiller, K.O. \& D.B. Jepsen. 1998. Effects of seasonality and fish movement on tropical river food webs. J. Fish Biol. 53: 267-296.

Woolnough, D.A., J.A. Downing \& T.J. Newton. 2009. Fish movement and habitat use depends on water body size and shape. Ecol. Fresh. Fish 18: 83-91.

Wootton, J.T. \& M.P. Oemke. 1992. Latitudinal differences in fish community trophic structure, and the role of fish herbivory in a Costa Rica stream. Env. Biol. Fish. 35: 311-319.

Wootton, R. 1998. Ecology of Teleost Fishes. Kluwer Academic, London, England.

Zippin, C. 1958. The removal method of population estimation. J. Wildl. Manage. 2: 82-90. 